\title{
INHERENT LIMITATIONS UPON IMPEACHMENT
}

The Constitution of the State of New York only inferentially declares who are subject to impeachment and is silent as to what constitutes an impeachable offence. In this it differs from the Constitution of 1777 , and is in sharp contrast to the Constitution of 1822. The constitutions of other states, with few exceptions, define impeachable offences and specify the officers who may be brought to trial before an impeachment court. While some carefully provide that this formidable process cannot be escaped by resignation or the cessation of official term, none prescribes that any sort of antecedent misconduct may be the subject of an impeachment proceeding.

In the impeachment of Governor Sulzer the charges which are the chief reliance of the prosecution relate to alleged acts occurring, it is true, in the brief interval between election and accession to the governorship, but nevertheless antedating his assumption of office. The question-and it is of the gravest import -is: Can the governor be impeached and removed for acts done prior to the time he took office? It matters not that the acts if committed were of such a nature as properly to draw upon him public odium. The question is whether any misconduct prior to inauguration can be the subject of impeachment proceedings. It is not the fortunes of a particular individual that are at stake. The discussion rises above personalities and is lifted from the arena of politics into the atmosphere of abstract principles. The value of a right decision is enhanced by the fact that the Constitution puts the possible control into the hands of what might be a minority of the entire membership of the court, and, as history teaches, minorities are often swayed by factional or partisan sentiment.

The New York State Convention of 1777 created a court for the trial of impeachments and the correction of errors under regulations to be established by the legislature. The court was to consist of the president of the Senate for the time being, the senators, the chancellor, and the judges of the Supreme Court, or the major part of them. Should an impeachment be prosecuted

This article was prepared and used, not publicly, before the beginning of the impeachment trial of William Sulzer as Governor of New York.Ed. 
against the chancellor or either of the judges of the Supreme Court, the person so impeached was to be suspended from office until his acquittal. Power to impeach all officers of the state for mal and corrupt conduct in their respective offices was vested in the representatives of the people in Assembly, but the consent of two-thirds of the members present was required to an impeachment. A special oath was to be taken by the members of the impeachment court "truly and impartially to try and determine the charge in question according to the evidence." A vote of two-thirds of the members present was essential to conviction. Punishment was not to extend beyond removal from office and disqualification to hold or enjoy any place of honor, trust or profit under the state. The convicted party was, however, to remain liable to indictment, trial, judgment and punishment according to the laws of the land.

Chapter 11, Laws of 1784, made provision for the procedure in impeachment cases. All impeachments were to be delivered to the president of the Senate, who was immediately to cause the court to be summoned. The court was then to cause the person impeached to appear or be brought before it to answer the charge against him. Upon his appearance he was to receive a copy of the impeachment and be allowed reasonable time to plead or answer. Whenever issue was joined the court was to appoint a time and place for the trial. The clerk of the court was to administer the special oath to the president of the Senate, who, in turn, was to administer it to the other members of the tribunal. In case of the impeachment of the president of the Senate, notice was immediately to be given by the Assembly to the Senate in order that another president might be appointed. These provisions were subsequently embodied in an act of the legislature passed February 12, 1801.

By the Constitution of 1822 the court was to consist of the president of the Senate (the words of the former Constitution "for the time being" having ben omitted), the senators, the chancellor and the justices (not judges) of the Supreme Court, or the major part of them. The power of impeachment was restricted: the Assembly was authorized to impeach all civil officers of the state for mal and corrupt conduct in office and for high crimes and misdemeanors. Impeachment could, however, be voted by a majority of the members elected. The words of the former Constitution, that the impeachment court should be instituted 
"under regulations to be established by the legislature" were dropped. In all other respects the impeachment provisions of the first Constitution were continued in force.

The only clause relative to impeachment in the Constitution of 1846, is section 1 of Article VI, which is as follows:

"The assembly shall have the power of impeachment, by the vote of the majority of all the members elected. The court for the trial of impeachments shall be composed of the president of the senate, the senators, or a major part of them, and the judges of the court of app-als, or the major part of them. On the trial of an impeachment against the governor, the lieutenant-governor shall not act as a membir of the court. No julicial officer shall exe cise his office after he shall have been impeached, until he shall have been acquitted. Before the trial of an impeachment, the members of the court shall take an oath or affirmation, truly and impartially to try the impeachment, according to the evidence; and no person shall be convicted, without the concurrence of twothirds of the members present. Judgment in cases of impeachment shall not extend further than to removal from office, or removal from office and disqualification to hold and enjoy any office of honor, trust, or profit, under this state; but the party impeached shall be liable to indictment and punishment according to law."

The changes made by this Constitution are, first, its failure to specify what should constitute an impeachable offence and, secondly, its addition of the sentence: "On the trial of an impeachment against the governor, the lieutenant-governor shall not act as a member of the court." The court itself was reconstituted, for the chancellorship had been abolished and a new court of appeals created to take the place of the old court of errors. The radical alterations wrought in the judicial system in 1846 were the substitution of an elective, for an appointive, judiciary, the amalgamtion of courts of law and equity, and the creation of a amalgamation of courts of law and equity, and the creation of a little debate, but the subject of the reconstitution of the judicial system was discussed at length. Voluminous as were the discussions upon this subject, there was no mention of the reasons which actuated the Judiciary Committee of the Convention in omitting all reference to impeachable offences, nor was there any inquiry from any delegate as to the cause for this omission.

The Constitutional Convention of 1867 proposed but one change in respect of impeachments. The Constitution of 1846 
had provided: "No judicial officer shall exercise his office after he shall have been impeached, until he shall have been acquitted." For this sentence there was substituted by the Convention of 1867 the following: "No judicial officer shall exercise his office, after articles of impeachment against him shall have been preferred to the Senate, until he shall have been acquitted." The judiciary article framed by the Convention of 1867 was ratified by the people in the election of 1869 and thereupon became part of the state's organic law. The question as to what constituted an impeachable offence seems never to have been discussed upon the floor of the Convention. No one asked what power of impeachment the Assembly possessed or with what jurisdiction the court of impeachment was clothed. The probabilities are that the attention of no member of the Convention was drawn to the subject.

The only change made by the Constitution of 1894 in the provisions regarding impeachment was in the sentence which reads: "On the trial of an impeachment against the governor, the lieutenant-governor shall not act as a member of the court." This sentence was altered to read: "On the trial of an impeachment against the governor or lieutenant-governor, the lieutenant-governor shall not act as a member of the court."

This brief review shows that although the earlier constitutions of the state contained definitions of impeachable offences, the definition was eliminated in 1846 and apparently without discussion; and that neither in the Convention of that year nor in any subsequent Constitutional Convention did any delegate inquire as to what latent meaning was behind the words "power of impeachment." The question now arises whether the power of impeachment under the present Constitution extends to all offences, whenever committed, which the court of impeachment may decide to be proper subjects for its cognizance. Has the Constitution created a court which may decide for itself winat constitutes an impeachable act and take cognizance of any charge at its pleasure? Is not this equivalent to conferring upon the court a discretionary power of removal? Was it the intention of the framers of the organic law to vest the impeachment court with such arbitrary discretion? In answer the language of Judge Story in an analogous case seems pertinent and forcible. Such a discretion "is so incompatible with the genius of our institutions that no lawyer or statesman would be inclined to countenance so 
absolute a despotism of opinion and practice, which might make that a crime at one time or in one person, which would be deemed innocent at another time or in another person."

It is claimed by some that the power of impeachment conferred by the Constitution of 1846 and continued in successive Constitutions reaches all offences whenever committed which the court of impeachment might decide to be proper subjects for its cognizance, or, differently stated, that the Constitution imports that the court of impeachment shall be the absolute judge of the extent of its own jurisdiction. There can be no review of the judgment of the court. Its judgment may not only depose the official brought before it, but preclude his holding any other political office in the state. The court for the trial of impeachments is in reality a court of criminal jurisdiction. The prosecution is a criminal prosecution. An impeachment is commonly likened to an indictment.

The argument for this broad jurisdiction of the impeachment court is thus presented in Bench and Bar, August, 1913:

"Our Constitution contains no specifications or limitations of the grounds for impeachment. The obvious and accepted purpose of such a proceeding is to remove an officer who is mentally or morally unfit for the duties and responsibilities of his office. So the framers of our Constitution have wisely omitted to define or delimit the causes for which an impeachment will lie. The sufficiency of the charges against the officer impeached is left to the determination of the Court for the Trial of Impeachments, which is composed of senators and judges of the Court of Appeals and within the scope of its jurisdiction is the highest court of the state. That court alone has authority to decide whether, upon the facts proved, the officer impeached is worthy of the trust and confidence of the people and fit to continue in office, and from the determination of that court there is no appeal."

It cannot be denied that authors and commentators have given expression to this point of view. The impeaching body has sometimes been styled the grand inquest of the state, with authority to ascertain whether any cause exists for the removal of a public officer, although he may have committed no indictable offence or broken any positive law. The jurisdiction of the impeachment court must upon this theory be commensurate; it must have authority to determine whether the offence charged has been committed and is of such a nature as to warrant a judgment of removal from office. Senator Charles Sumner of 
Massachusetts was an able exponent of this theory. In his opinion pronouncing President Andrew Johnson guilty upon all the impeachment articles that had been preferred by the House of Representatives, he argued that impeachment was a power broad as the Constitution itself and applicable to the president, vicepresident and all civil officers through whom the Republic might suffer, or in any way be imperilled. Said he:

"Show me an act of evil. example or influence committed by a president, and I show you an impeachable offence, which becomes great in proportion to the scale on which it is done and the consequences which are menaced. The Republic must receive no detriment; and impeachment is one of the powers of the Constitution by which this sovereign rule is maintained."

The Sumner theory was not sustained by the verdict of the Senate. Almost all the state constitutions adopted since the Johnson trial have scrupulously defined impeachable offences. The sentiment of the country as expressed in constitutional law since that trial has denied the existence of such boundless authority in the impeaching body or the impeachment court unless, perchance, the repetition in the New York Constitution of 1894 of the provisions of the Constitution of 1846 be regarded as approval of the Sumner theory. This doctrine is tantamount to the broadest kind of recall of public officials, limited only by the formalities of an impeachment trial, in which, however, the spirit of faction may destroy all sense of justice. It would be particularly dangerous in its application to judges. However attractive the notion of a tribunal invested with power to condemn and degrade a public official for what it may in its sovereign judgment deem to be adequate cause, it is subversive of all sound principles, if not at war with.all precedents. The proposition of the advocates of this extraordinary power is nothing less than this: That a court has been constituted with power to determine the extent of its own jurisdiction, which may be narrower or broader as the. demands of party or faction require. The court supposedly vested with this authority may, so far as the potential part of it is concerned, be composed of less than a majority of all the persons entitled to sit in it! In other words, twenty or it may be twenty-one of the fifty-one members of the State Senate and of the seven or ten judges of the Court of Appeals, constitute the court, for this small number may not only decide what is an impeachable offence, adjudge the accused guilty and remove him 
from office, but may also debar him from ever thereafter holding an office of trust or profit within the state. ${ }^{2}$ Could a scheme better fitted to enable faction to control government ever have been devised? The impeachment and conviction are in reality ex post facto, for it could not be known in advance that the act charged would come within the scope of impeachable offences and the court is the sole judge of its own jurisdiction! Such a system, however eloquently its apologists may plead for it, is a mockery of constitutional government and would constitute the worst kind of tyranny.

That the full consequences of the views of the impeachment managers may be appreciated it must be remembered that the judges of all the higher courts are amenable to impeachment. Should the spirit of party or faction become sufficiently formidable hardly a judge upon the bench would be secure against a movement to depose him. He could be removed not alone for some transgression in office but for any misdeed, however remote in time, which the court of impeachment might in its absolute discretion choose to consider ground for unseating him. Once given such free range, hatred or vindictiveness would surely find some charge upon which to impeach, and perhaps convict. The purer and less blemished the character of the jurist, the higher his reputation, the more commanding his position, the greater might be the danger of his removal from office, because in the fearless discharge of his duties he might have incurred the enmity of powers capable of influencing legislative bodies for sinister ends.

Since the Constitution of New York vests the "power of impeachment" in the Assembly, the question at once arises, what is the extent of that power? Is the power a well defined thing? Are there unerring precedents to which appeal can be made? Was it the intention of the people to clothe the court for the trial of impeachments with jurisdiction to treat any offence as an

2 In New York a constitutional quorum of the court would consist of 26 senators and four judges of the Court of Appeals, or if the Supreme Court justices designated to sit in the Court of Appeals, thereby become members of the caurt, it would consist of 26 senators and six judges. A vote of two-thirds of the tribunal, which would be 21 or 22 , according to circumstances, could convict. If the practice followed in the Barnard case and in the Archbald case should control, it would be in the power of 16 or 17 members to impose the sentence. In those cases it was held that while a two-thirds vote was necessary to convict, a majority vote could determine the judgment. 
impeachable one? The power as exercised in history has never, I think, been held to extend so far as to include acts committed before assumption of office.

In order to determine the meaning of the words the "power of impeachment" as used in the organic law of this state, light may be sought from the practice in England, the history of impeachment cases under the Federal Constitution and the earlier cases in this state. The question may then be examined upon principle.

1. The practice of impeachment by the Commons at the bar of the Lords dates from the reign of Edward III. Anson, in his Treatise on the Law and Custom of the English Constitution, says:

"It shou'd be distinguished from the system of appeals in Parliament by which private accusers endeavored to get a trial before Parliament of the person whom they charged with an offence. The Iords had declared in 1387 that the case of any high crime touching the King's person and the state of his realm committed by the peers of the realm with others shoult be dealt with in Parliament. Such a court bound by no settled rules, and disregarding the advice of the judges might create the offence and the penalty in the course of its judicial proceedings; such appeals were forbidden by Henry IV. They revive in an altered form in the Acts of Attainder by which in the later part of the fifteenth and throughout the sixteenth century persons who had played for a high stake in politics and lost it or who by no fault of their own chanced to be on the unpopular side, were hurried to death with no form of trial."

Elsewhere in the same Treatise, Anson says:

"Impeachment was a valuable weapon when it was first instituted in the fourteenth century and again when its practice was revived by the Commons in 1621 under kings who were ready to sustain the Constitution to the point of rebellion. It was then important to strike a heavy blow at the instruments of the royal will. ***

"The Commons were prepared to assume that the acts of the gnvernment were the acts of the King's Ministers, not of the King himself; but they wanted to be able to punish an erring Minister if they could be sure of punishing the right man. The punishment was clumsy enough, impeachment or attainder resulting in exile, imprisonment, fine or death-until it came to be understood that the expression of popular disapproval shown by a vote of the House of Commons or the results of a general election was a sign that the entire Ministry must be changed or that a Minister who had acted on his own responsibility must leave office." 
"The right of impeachment begins in 51, Edward III, in a time of great administrative abuses under a king in his dotage" (Gneist, History of English Constitutions, Vol. II, p. 18).

As early as 15, Edward III, Parliament resolved:

"No peer of the land, crown official, or other, on account of his office, can be brought before the court, $* * *$ rendered responsible or judged otherwise than through the award of the peers in Parliament,"

which seems to imply that it was misconduct in office for which an official of the government was to be arraigned with a view to his removal. Clashes may have occasionally occurred between the House of Commons, the indicting or impeaching body, and the House of Lords, the impeachment court, as for example, in the case of Edward Fitzharris in 1681. Fitzharris, says Green, in his History of the English People, was not a public officer, but a mere informer, and was entitled as a commoner to a trial by a jury of his peers in the courts of the common law. When the House resolved to impeach, the Lords suspended the proceeding. The House in reply passed a resolution declaring it to be their undoubted right to impeach any peer or commoner for treason or any other crime or misdemeanor. This was in accordance with the broad claim made from time to time by the Commons, and occasionally accepted by the Lords, that private individuals were amenable to impeachment. The two Houses were in accord in the case of Doctor Sacheverell, who was impeached and punished for preaching seditious and treasonable sermons, in 1710.

The earliest authenticated impeachment in England is said by some authorities to be that of Roger Mortimer, Earl of March, for treason, in 1330. According to others the first case was that of William, Lord Latimer, against whom charges of gross malversation in office were presented by the Commons, near the close of the reign of Edward III. After a trial before the Lords, Latimer was condemned to imprisonment, as well as forfeiture of his place. Between the impeachment of Lord Bacon and the revolution of 1688 there were about fifty cases of impeachment, nineteen having taken place in the first three years of the Long Parliament. From 1688 to the close of the reign of George I (1727) there were fifteen. There was one in the reign of George II, that of Lord Lovatt in 1746 for high treason. This 
was followed by the memorable trial of Warren Hastings (17881794), and by that of Lord Melville in 1806.

Lord Melville's trial merits notice because its abortive result tended to bring the process of impeachment into disrepute. Melville, an intimate friend of William Pitt and Treasurer of the Navy, had withdrawn $£ 10,000$ of its funds from bank, and when called to account, refused, as he said, "from motives of public duty, private honor and personal convenience" to reveal the use which had been made of the money. The managers of the impeachment charged that his acts were crimes; his counsel maintained that there was no statute under which they were punishable. With this view a majority of the Lords concurred and Melville was acquitted. Macaulay doubtless had this case in mind when, in 1841 , in his essay upon Warren Hastings, he penned the following paragraph:

"In truth it is impossible to deny that impeachment, though it is a fine ceremony and though it may have been useful in the seventeenth century, is not a proceeding from which much good can now be expected. Whatever confidence may be placed in the decision of the Peers on an appeal arising out of or-linary litigation, it is certain that no man has the least confidence in their imp:rtia!ity, when a great public functionary, charged with a great state crime, is brought to their bar. They are all politicians. There is hard'y one among them whose vote on an impeachment may not be confidently predicted before a witness has been examined."

Records of many of these impeachment trials are no longer extant, but it is reasonably safe to affirm that no case that arose under the Plantagenet, the Tudor, or the Stuart kings went so far as to question the acts of a public servant before he took office. Impeachment was too vital, too dynamic, a proceeding to be thus diverted. Its processes were direct. Royalty was shielded from punishment by the maxim that the king could do no wrong; but if a minister who was the willing tool of an arbitrary monarch, a Strafford, for example; could be arraigned and brought to trial for acts of tyranny and punished by imprisonment, exile, or even death, few ministers would for the sake of royal favor dare to incur such an ordeal. The men who were fashioning a weapon that would compel ministers to acknowledge responsibility to the House of Commons struck directly at misconduct in office, and probably never imagined such an employment of the process of impeachment as is suggested in these 
latter days. And as soon as the House of Commons became able so to govern the conduct of ministers as to render it impossible for them to conduct public business without parliamentary support, impeachment ceased to have practical value. And since judges have become removable upon the joint address of both Houses of Parliament, a principle established during the reign of William III, the process of impeaching judges has fallen into desuetude.

The phrase "treason, bribery or other high crimes and misdemeanors" which was taken by the framers of the Federal Constitution from the parliamentary law of England, may never have had a fixed and defined meaning in that country. The present argument does not require that it should have had precise definition. It may have been, as has been well said, "a generalization as broad as the mischief against which the process of impeachment guards": nevertheless it would have been misapplied and emasculated if aimed against conduct out of office save in the exceptional cases of private citizens,-as, for instance, in the case of Doctor Sacheverell. Those who, from time to time, have assumed that the power as exercised in England was without any restriction as, for example, Judge Lawrence, a distinguished member of the House of Representatives during the impeachment of Andrew Johnson, and author of the brief which was used by the impeachment managers, adduce no precedent or authority to sustain their assertions. Judge Lawrence quotes from John C. Hamilton's Annotations upon The Federalist that

"in the delineation and construction of those [impeachable] offences the nature of the proceeding can never be tied down by the strict rules which, in common cases, limit the discretion of courts; that the discretion of the court for the trial of impeachments, thits unlimited in its proceedings, is 'an awful discretion', and that its exercise was contemplated to be applied towards the most confidential and the most distinguished characters of the community." Those who seek to expand the power of impeachment by surrounding it with such an atmosphere of awe, deal only in generalities, never cite a case; their only reliance is upon the words which have been inherited from the English practice, to wit, "high crimes and misdemeanors." These words, it may be acknowledged, invest the impeachment court with "an awful discretion"; but nevertheless they designate a circumscribed area of jursidiction, however extensive it may be. It never has included the acts of a person before he took office. Those who argue for the exist- 
ence of such a power may well be asked to produce atthority for it. The burden is assuredly upon them.

2. Nothing in the history of impeachment proceedings in this country lends any aid to this claim. The discussions in the convention that framed the Constitution of 1787 give it no support. The debates are throughout pervaded with the idea that the subject of impeachment was official misconduct, that is, conduct in office. Under the Federal Constitution there have been nine impeachment trials. The earliest was that of Senator William Blount of Tennessee in 1797, 1798. The charge against him was that he had been guilty of treasonable negotiations with Great Britain for the transfer of New Orleans. The House impeached, the Senate expelled, him, and then proceeded to try him upon the impeachment. Blount's counsel challenged the jurisdiction of the impeachment court. upon two grounds: (1) that a senator was not an officer of the United States within section 4, Article II, of the Constitution, which provides that "the President, VicePresident, and all civil officers of the United States shall be removed from office on impeachment for and conviction of treason, bribery, or other high crimes and misdemeanors"; (2) that owing to his expulsion he had ceased to be a senator. The Senate sustained the first plea and the case was dismissed.

Concerning Blount's impeachment, Jefferson thus expressed himself in a letter to Madison, February 8, 1798:

"I see nothing in the mode of proceeding by impeachment but the most formidable weapon for the purposes of dominant faction that ever was contrived. It would be the most effectual one of getting rid of any man whom they consider as dangerous to their views. $* * *$ I know of no solid purpose of punishment which the courts of law are not equal to and history shows that in England impeachment has been an engine more of passion than of justice."

In 1803 Judge John Pickering of the Federal Court of New Hampshire was impeached and afterwards removed for drunkenness and profanity on the bench. Samuel Chase, one of the associate justices of the Supreme Court of the United States, was impeached in 1804 for various offences, all said to have occurred in office, and was tried in 1805 before the Senate. At the trial, which resulted in Chase's acquittal, Aaron Burr, then Vice-President of the United States, presided, and history records that he made a model presiding officer: In 1831 Judge James H. Peck of the Federal Court of Missouri was impeached for punishing 
as contempt of court certain criticisms upon his judicial opinions. He was defended with great ability and eloquence by William Wirt and acquitted. In 1862 Judge West $\mathrm{H}$. Humphreys of the Federal District Court of Tennessee was impeached upon the charge of aiding the rebellion and removed from office. His treasonable conduct occurred during his incumbency of the bench. Next came President Johnson's case. All the articles of impeachment referred to some form of misconduct in office. Even the speeches in which he was said to have made improper and disrespectful reference to Congress were delivered during his term of office. In 1876 Secretary of War W. W. Belknap was impeached for bribery in office, but he resigned while the impeachment was in preparation, and President Grant accepted his resignation. Articles of impeachment were subsequently preferred. Belknap denied the jurisdiction of the court, as he had ceased to be an officer of the United States before the proceeding was begun. A majority of the Senate voted to overrule the plea, the trial proceeded and resulted in failure to convict. The senators were undoubtedly influenced by the fact that as he had resigned, the Senate had lost jurisdiction of the case. Judge Charles Swayne of the District Court of the United States, District of Florida, was impeached in 1905 for misconduct in office and acquitted.

In 1912 articles of impeachment were preferred by the House of Representatives against Robert W .Archbald, United States Circuit Judge, sitting as a member of the Commerce Court. It was the first successful impeachment of a Federal judge since the Civil War and a demonstration of the efficiency of the time-honored remedy for checking judicial misbehavior. Of the thirteen articles presented by the managers six arraigned the respondent for misconduct as a member of the Commerce Court, six related to his behavior while a district judge, and the final one was a blanket indictment. The respondent denied the jurisdiction of the Senate to make inquest into his conduct as a district judge, and while the outcome was a verdict of guilty upon the articles charging improprieties in the office from which the Senate removed him, its vote upon the remaining articles implies that the Senate held to the conservative opinion that antecedent offences could not be made the subject of impeachment. Senator Borah, after expressing doubt whether a man could be impeached for misdeeds in an office he had ceased to hold, said he would hesi- 
tate to establish such a precedent. Senator Works declared it to be his opinion that such misconduct could not be made a cause for impeachment, and Senator Brandegee expressed similar views. Senator Root, in a brief written opinion, stated that he had no doubt that the respondent was liable to impeachment for acts done while a district judge and that the Senate had jurisdiction to try him for such acts; and Senator Lodge concurred with him. Senator Owen declared that it would be against public policy that advancement to a higher place should preclude impeachment for high crimes and misdemeanors in the prior office, not discovered until after promotion had taken place.

3. There have been few impeachment cases in the history of New York State. They may briefly be summarized.

The first was the case of John C. Mather, Canal Commissioner, in 1853. The charges against him related apparently to misconduct in office. The next was that of Robert C. Dorn, Canal Commissioner, who was tried in 1868 for misconduct in office, and acquitted.

The next case was that of George G. Barnard, a justice of the Supreme Court, who was tried in 1872. He was found guilty upon a number of the impeachment articles, removed from office, and declared to be disqualified from thereafter holding any office of honor, trust or profit in this state. It is sometimes said that Judge Barnard was tried for misconduct before he took office. Part of the testimony taken in the preliminary investigation related to charges of misconduct during his first term as judge. Upon the trial of the impeachment proceedings his counsel strenuously opposed admission of proof to sustain these charges, but the vote of a majority of the impeachment court favored its reception. As to the significance of this vote I quote an opinion which, having been pronounced long before the institution of proceedings against Governor Sulzer, cannot have been biased by recent events. In his "Constitutional History of New York", Mr. Charles Z. Lincoln says that the decision of the impeachment court which sat in Judge Barnard's case

"can scarcely be deemed an authority for an impeachment where all the alleged misconduct occurred during a previous term, for the reason that some of the charges on which the judge was convicted related to misconduct during his present term, and these charges were obviously within the jurisdiction of the court, and a conviction on them was sufficient to sustain its judgment." 
Furthermore, it might be said that for purposes of impeachment the judicial term was an entirety, and that acts done during the earlier term might properly have been considered as reflecting a light upon the character and temperament of the judge and helping to explain conduct during the later term. But the Barnard case is no authority for an investigation into acts done altogether before entry upon office. No case that goes so far was cited by counsel for the prosecution. A quotation from the argument of Mr. William C. Beach, leading counsel for Judge Barnard, may be pertinent. He said:

"I may have a morbid sentiment, sir, upon this subject; but it is, to me, a remarkable spectacle that a court of impeachment should be again and again convened in this state, and upon every occasion we are driven to reason upon principles in regard to the scope of its jurisdiction and its mode of procedure; that there is no settled doctrine; that there is no organized mode of procedure by which this court is to be governed; a court whose decisions affect the most vital interests of the citizens of this government, and of the government itself, left entirely to the spontaneous guidance of its convictions at the time it is called upon to act!"

So far as there has been any expression of opinion in this state it has been adverse to the broad claim of power. In the year 1853 when removal proceedings were contemplated against one Philo C. Fuller, the Assembly asked its Judiciary Committee for advice whether a person could be impeached who at the time of his impeachment was not the holder of an office under the laws of this state; and whether a person could be impeached for mal conduct or offences in a prior term of the same or any other office. The committee reported to the Assembly as its opinion that a person whose term of office had expired was not liable to impeachment and that the Constitution intended to confine impeachments to persons in office and for offences committed during the term of office from which the person was sought to be removed. ${ }^{3}$

3 The essence of the committee's argument is as follows:

"That the person impeached must have been in office at the time of the commission of the alleged offence, is clear from the theory of our government, viz: that all power is with the people, who if they saw fit might elect a man to office guilty of every moral turpitude, and no court has the power to thwart their will, and say he shall not hold the office to which they have elected him; a contrary doctrine would subvert the spirit of our institutions.

"Neither by the Constitution nor by our laws is there any pericd linlited, in which an impeachment may be found; it is but fair, therefore, to 
In adopting the committe's report the Assembly passed the following resolution:

"Resolved, (1) That a person whose term of office has expired is not liable to impeachment for any misconduct under section 1 of Article VI of the Constitution;

"(2) That a person holding an elective office is not liable to be impeashed under sertion 1, Article VI of the Constitutino, for any misconduct before the commencement of his term, although such misconduct occurred while he held the same or another office, under a previous election."

This resolution was in accord with the idea then embodied in the statutes of the state. The act of 1784 under which the first court for the trial of impeachments and the correction of errors

infer, that the intention was to confine the time to the term of office during which the offences were alleged to have been committed, indeed, any other conclusion would lead to results, which could not be sustained, for who can say, but that the people knew of this mal-conduct, these offences, and elected the individual notwithstanding; true, an extreme case might be put of fraud committed on the last day of the term of an office, to which office the individual might be immediately re-elected; yet, who could say this was not known to the people? How is the matter to be settled? The mere statement of the question shows the dilemma in which we would be placed at every election, if the tenure or stability of an office depended upon a legal enquiry as to whether the people knew the characters of the individuals they had elected to office, and had exercised a proper discretion.

"Hoivever much it may be desired to have men of high integrity and honesty fill our public offices of trust and honor, yet by our Constitution and the fundamental principles of our Government, no particular scale of integrity, honesty or morality is fixed. No inquisition as to what character had been, can be held; it is enough that the people have willed the person should hold the office. And the courts, which are but the mere creatures of the public, will have no power to interfere.

"The Constitution provides, as we have seen, that a persan cannot be impeached after he is out of office, then if the same person should be re-elected to the same office, a year afterwards, would this right of impeachment be revived? In fine, by, his re-election, would he incur any other liabilities, or acquire any cther rights than those incident to his present term of office? We think a moment's reflection would convince every person that it could not.

"Again, could an officer be deprived of his present office by impeachment for mal-conduct, in another and different office, or even the same office, twenty year's before his present term commenced? If not, could he after one year or one moment had elapsed? Where is the difference in the principle; the time is nothing; the question is, is he out of office, it matters not if he is the next moment inducted in." 
was instituted, was, with no important change, re-enacted in 1801, and again upon the general revision of the statutes of the state in 1830.

In 1881 the legislature enacted a new Code of Criminal Procedure. It contained a section which may be urged as decisive in Governor Sulzer's case, for it placed clear restrictions upon the power of impeachment. Section 12, the section in question, is as follows:

"The court for the trial of impeachments has power to try impeachments, when presented by the assembly, of all civil officers of the state, except justices of the peace, justices of justices' courts, police justices, and their clerks, for willful and corrupt misconduct in office."

This statute, if constitutional, should remove all doubt as to the inability of the impeachment court to inquire into offences antedating the Governor's assudption of office. The statute expresses the legislature's view of the jurisdiction of the court of impeachment. It is, to paraphrase Chancellor Kent, "a legislative interpretation" of the Constitution, which may be viewed as an usurpation by the legislature or as a constitutional enactment according to the bias of advocacy. Of an earlier statute-the law as revised in 1830, which, following the Act of 1784, prescribed that impeachment could take place only for mal and corrupt conduct in office-Henry $C$. Murphy, who was one of the state senators at the time of Judge Barnard's impeachment and a member of the impeachment tribunal, used the following language in one of his addresses to the court:

"There is a statute of our State, passed in 1830, before the adoption of the present State Constitution, which enacts precisely the clause that is contained in the State Constitution of 1822, which provides that 'all civil officers may be impeached for mal and corrupt conduct and for high crimes and misdemeanors'. Now, it seems to me, without referring at all to what may be impeachable at common law, that statute, expressly providing that 'all civil officers may be impeached for mal and corrupt conduct,' and remaining unrepealed, the present Constitution may be held to refer to and adopt it as a part of the law of the land, and, therefore, a judge may be impeached for any maladministration or corrupt administration, and that it need not be a crime indictable in its nature, if, in the opinion of the court, it is a maladministration of the law."

If Senator Murphy's reasoning was tenable, by analogy the statute of 1881 is constitutional. 
When the Convention of 1894 sought to revise and amend the State Constitution it was presumably aware of the enactment of the Code of Criminal Procedure, and with that knowledge it placed in the new Constitution a provision which in effect had formed part of every prior Constitution of the State, and which is section 16 of Article I of the Constitution of 1894:

"Such parts of the common law, and of the acts of the legislature of the colony of New York, as together did form the law of the said crlony, on the nineteenth day of April, one thousand seven hundred and seventy-five, and the resolutions of the Congress of the said colony, and of the convention of the State of New York, in force on the twenlieth day of April, one thousand seven hundred and seventy-five, and the resolutions o fthe Conor been repealed or altered; and such acts of the legislature of this State as are now in force, shall be and continue the law of this State, subject to such alterations as the legislature shall make concerning the same. But all such parts of the common law, and such $r f$ the said acts. or parts thereof, as are repugnant to this Constitution, are hereby abrogated."

The Code of Criminal Procedure having been passed in 1881, thirteen years before the assembling of the last Constitutional Convention, and the Constitution providing that every statute not expressly repugnant to its provisions "shall be and continue the law of the State," the act of 1881 is constitutional unless it can fairly be said to be repugnant to the Constitution itself. The word "repugnant" means "inconsistent with", "contrary to", "in conflict with", "irreconcilable with". None of these terms is applicable. There is no repugnancy, but, on the contrary, in the language of Senator Murphy, the statute "may be held to be and to have been adopted by the Convention as the law of the land". It is presumably constitutional, and the burden is upon those who claim otherwise to establish its invalidity. If the legislature was competent to enact it, the impeachment court is interdicted from receiving evidence that does not tend to establish willful and corrupt misconduct in office. The whole body of statutory law does not fall whenever a new or revised Constitution is adopted. Many statutes would have only frail support if their validity depended upon express warrant in the Constitution itself. But wherever they antedate the Constitution they are adopted along with it when it is ratified by the people, and, unless plainly incompatible with it, they continue to be the law of the state. Thus the constitutionality of the act defining impeachable offences may be upheld. 
Constitutional authority to enact the provision of the Code of Criminal Procedure restricting impeachment to wilful and corrupt misconduct in office may be found in the provisions of section 7, Article X, of the Constitution of 1846, which is continued unchanged in the Constitution of 1894 . Section 7, Article X, is as follows:

"Provision shall be made by law for the removal for misconduct or malversation in office of all officers, except judicial, whose powers and duties are not local or legislative, and who shall be elected at general elections, and also for supplying vacancies created by such removal."

Whatever may have been the purpose of this provision, it gives the legislature power to provide for the removal of certain state officers, including the governor and the lieutenant-governor, for misconduct or malversation in office. Here the Constitution itself contains the idea that the cause of removal should be misconduct in office. This constitutional provision may be likened to the language frequently employed in the Federal Constitution, - "Congress shall have power to enforce this provision by appropriate legislation,"-the meaning being that the legislature may determine what are impeachable offences.

Section 12 of the Code of Criminal Procedure is not repugnant to the Constitution for these reasons: (1) it is authorized by section 7 of Article X. It makes provision for the removal of the governor and other officials; (2) being a statute passed prior to the adoption of the Constitution of 1894 the language of that Constitution expressly continues it in force unless it is irreconcilable with the Constitution itself. The statute would seem to have been constitutionally adopted and to have become part of the law of the State.

4. Inquiry into the acts done by an elected official before his accession to office is forbidden by a "higher law" than the Constitution, which is that an elected servant is immune from prosecution by impeachment save for misconduct in office. The reasoning of Senator Owen in the Archbald case may have been sound, - that it should not be possible to interpose promotion as a bar to the impeachment of an appointed officer, but in the case of a person elected to office, public policy prohibits any inquest by an impeachment court or other removing authority into his conduct prior to his inauguration. It would be a pernicious doctrine, susceptible of no end of abuse, that would allow an impeachment 
court to stay or reverse the results of a popular election. In the long run it is far better for democracy that it should endure the ills resulting from its unwise selections than that some heroic recall remedy should be provided. The fundamental objection to the broad jurisdiction, "the awful discretion", of an impeachment court is that the people never intended to clothe any governmental agent with discretionary power to remove its elected servants, for that would be a power to nullify the results of an election at the will of the removing authority. No power has been vested in any impeachment court to revoke the popular verdict, to depose the unfit. The people are nevertheless not compelled to endure the presence of a convicted criminal in an exalted office. The Penal Code in New York expressly prescribes that

"A sentence of imprisonment in a state prison for any term less than for life, forfeits all the public offices, and suspends, during the term of the sentence all the civil rights, and all private trusts, authority, or powers of, or held by, the person sentenced."

In popular governments the people are habitually jealous of their rights. They tenaciously insist upon the right of election, - even the election of judges-when it would be better that these should be appointed. They never willingly tolerate interference with their prerogative of choosing their officers. As a check upon the wrong-doing of public servants, the people have lodged in certain constitutional agencies power to punish for misdeeds in office. This limited power of removal has been delegated to various branches of government, executive, legislative, and judicial; but the power thus delegated is circumscribed. Power to correct the people's mistake in electing-power to recall the servant-was never meant to be conferred. If the power to remove were as broad as the power to elect, one could be used to neutralize the other. A court invested with absolute power to determine whether the officer impeached is "fit to continue in office" is a tribunal that in effect may remove at will. There should be some limitation upon its jurisdiction, otherwise in the last analysis it has jurisdiction to remove at pleasure. The peop!e elect and they recall at the close of official terms. To assume that they have given unlimited power of recall to any agency of government seems to me to conflict with the rights which they have reserved to themselves. The Constitution of New York provides various methods of removal. Officers may be impeached or may be removed by a more summary and less solemn 
process, as in the case of the superior judges by a joint vote of the two houses of the legislature; in the case of county judges by action of the Senate, and in the case of certain county officers - the sheriff, the county clerk, the district attorney, and the register in counties having registers, by the governor. . All these are constitutional methods of terminating the official life of the people's elected servants. Sound policy, if not also the Constitution, requires that removal be only for cause. Otherwise the power to remove would be equivalent to a power to nullify the people's will in electing. The people have never knowingly granted to any court of impeachment or other removing authority the power to remove from office for reasons which that court in its uncontrolled discretion may decide to be sufficient, for that would be creating an instrumentality to defeat the people's own will. To describe the power of impeachment as "an awful discretion"-if thereby it is meant to assert that the jurisdiction of an impeachment court is boundless in extent-is to enunciate a doctrine that runs counter to fundamental ideas of popular government. The people have clothed the court with no power to unseat their elected officers for any cause which upon the initiative of the Assembly the court may choose to consider an impeachable offence. No such commission, we contend, has been given to any authority vested with power to remove.

The subject may be regarded from another point of view. No court, however high and solemn its functions, is vested with unlimited jurisdiction. No tribunal can or should be so constituted as to be in all circumstances the sole judge of its own authority. No appeal lies from its decrees, yet it may decide for itself what constitutes an impeachable offence, may depose the offender and forbid his election to office in future! If this be not arbitrary power it would be hard to define what arbitrary power is. To reply that the people have conferred it is to beg the question, for the inquiry is: What is the nature and degree of the pawer conferred upon the impeachment court? To those who urge that its jurisdiction is such that no man in advance of its decision can say how far its authority extends-that it decides for itself what cases come within its purview-the answer is that the makers of the Constitution never meant to confer upon an agency of government-however important the agency-an unlimited power, and that the Constitution can confer no such authority upon any person, agency or court. That it was not. knowingly and deliberately conferred would seem clear. 
It is said by way of answer that every court of last resort is the sole arbiter of its own jurisdiction-that the Court of Appeals, save in cases involving Federal questions, determines over what subjects it has cognizance, and that the Supreme Court of the United States likewise decides whether it may entertain a controversy brought before it. But neither of these tribunals has any such irresponsible power as is claimed for the court of impeachrnent. The jurisdiction of the Court of Appeals is defined by the State Constitution, that of the Supreme Court of the United States by the Federal Constitution. Should either go beyond its authority, its judgment would be voicl, for no principle of law is more firmly settled than this-that when a court exceeds its jurisdiction its acts are a nullity, and lack of jurisdiction may be urged at any time. But whether this be so or not, the juidges would be impeachable for usurpation of authority. Who, however, could impeach the members of the court of impeachment for an unwarranted exercise of power, since it is the sole, absolute and final judge of its own powers? A legislature elected in retaliation might prefer articles of impeachment and the court summoned to pass upon the alleged offenders might uphold the charge and remove them from office. That process, however, might go on until the spirit of reprisal was exhausted, and nothing would be. settled. Government would not then be proceeding apon constitutional principles, but upon the notion that whatever a temporary majority may chose to do is right, which would prove as fatal to liberty as to sound constitutional development.

A doctrine leading to such results must be abandoned. The court of impeachment, like all other courts in civilized countries, can act only within the scope of its manifest powers. It is not a law to itself, it is the creature of law. It cannot usurp authority, but must find a specific granty to justify its action. Its powers do not reach so far as to enable it to pass judgment upon conduct antedating the assumption of office or permit the removal of any state official for any cause deemed fit, which can be established by evidence.

These views accord with those expressed by the late $\mathrm{Mr}$. Justice Gaynor in Matter of Guden v. Dike (37 Misc., 390). Governor Morton removed Guden, sheriff of Kings County, from office and appointed his successor. When the new sheriff took possession of certain books and papers of the office, Guden applied to the Supreme Court for an order compelling the delivery of the books 
and papers to him on the ground that his alleged removal was an unconstitutional and void act. The gravamen of the charge against Guden was that in October, 1901, and prior to his election to the office of sheriff, he had "made a corrupt promise to and agreement with Bert Reiss to appoint him counsel to the sheriff in consideration of his (Reiss') activity and influence in securing influence and votes for that office in the election of 1901." Mr. Justice Gaynor decided that this was an act done before Guden took office and that the governor's power of removal extended only to acts performed by the sheriff in office. The Appellate Division decided that the performance of the corrupt agreement was necessarily postponed to a period when Guden should become a public officer and that the relation of the promise to the subsequent official tenure was so close as to make the act of entering into such a corrupt agreement affect the usefulness of the officer as clearly and directly as could any misconduct committed wholly after the official term began. In other words, the promise was inchoate until Guden's election made it effectual. Although the Appellate Division took the more correct view of the transaction, the opinion of the Special Term Judge contains much that has enduring value. Reasoning upon the assumption that the act for which Guden was removed had been done and completed prior to his accession to office, Mr. Justice Gaynor properly declared that only acts in office could be the subject of attack, and he added:

"To hold that it (the Constitution) also means acts committed before the official came into office, would be to read into the clause something which is not there, and which would be most astonishing in this or any other free state if it were there; for it would allow an appeal from the people who elect their officials to the governor on the question whether the officials of their choice should serve or not. The plain purpose of the provision is only to make the official responsible as an official, i.e., for his conduct in office to the governor and not to make him responsible or answerable at all in his private character. $* * *$ The common law power of removal was for neglect or misconduct in office only, as will be seen later on, except for indictment and conviction of a crime so infamous as to render the offender unfit to hold any office. It was in this light that this clause was framed and it is this power and no other that was intended to be put in the Constitution. ***

"The power of removal for neglect or misconduct in office hact been exercised from time immemorial, and needed to be lodged 
somewhere, and the people lodged it in this instance through the Constitution with the Governor. That they should confer such power in respect of neglect or misconduct in office was in accordance with our system of government, its history and traditions, and established law and practice. That they should mean to go further, and extend such power to the removal of officials at the will of the Governor for anything he saw fit, whether committed by them before or after they came into office, is an idea so contrary to our theory of government, its history and traditions, and immemorial common law and practice, that it cannot be entertained, since it is not expressed by the people in unmistakable words. The setting up of such an appeal from the electors to the Governor was never dreamed of."

Nothing in the opinion of Mr. Justice Bartlett at the Appellate Division conflicts with these declarations, for the Appellate Division concluded that the act in a sense was done or completed after the sheriff took office.

The Court of Appeals decided that the Governor's power of removal was executive, and not subject to judicial review where it was shown that a charge within the contemplation of the Constitution had been made against the sheriff and a hearing been had. This limitation upon the executive power is made especially clear in Judge O'Brien's opinion. A "charge of some official misconduct" is a prerequisite to action by the Governor. The opinion of Chief Judge Parker seems to imply that the Governor's power to remove was practically absolute, where charges of some kind had been filed with him. If so, Judge O'Brien's view is the sounder and accords with the doctrines quoted from Mr. Justice Gaynor's opinion.

In considering the Guden case, Mr. Lincoln says that in his opinion

"the Governor's power of removal. is executive and he possesses exclusive authority to determine the sufficiency of the reasons which, in his judgment, justify the removal; and such determination is not subject to judicial review; but the courts may inquire into the proceeding's for the purpose only: of ascertaining whether the Governor had jurisdiction in the particular case, and whether the procedure was such as the Constitution and statutes require."

By parity of reasoning the power of removal vested in the court of impeachment or, in other words, the jurisdiction of that court, is restricted. It is no awful tribunal possessed of ability to depose an official at will. Our system of government does not warrant the exercise of any such irresponsible power. The 
idea of the existence of arbitrary power in any individual, body or tribunal was vehemently and eloquently repelled by Edmund Burke in his address upon the impeachment of Warren Hastings. To the plea of Hastings that he possessed arbitrary power in India which it was his duty to exercise at times, Burke made this immortal answer:

"He have arbitrary power! My Lords, the East-India Company has not arbitrary power to give him; your Lordships have not; nor the Commons; nor the whole Legislature. We have no arbitrary power to give, because arbitrary power is a thing, which neither any man can hold nor any man can give. *** Law and arbitrary power are in eternal enmity. Name me a magistrate, and I will name property; name me power and I will name protection. It is a contradiction in terms; it is blasphemy in religion; it is weakness in politics to say that any man can have arbitrary power. In every patent of office the duty is included. For what else does a magistrate exist? To suppose for power is an absurdity in idea. Justices are guided and governed by the eternal laws of justice, to which we are all subject."

And he added that never in the history of the world had any one heard

"of an officer of government who is to exert authority over the people without any law at all, and who is to have the benefit of all laws and all forms of law, when he is called to an account."

The same principles were enunciated by Mr. Benjamin R. Curtis in his defense of Andrew Johnson in language that may well be recalled today. Curtis argued that the words "high crimes and misdemeanors" implied the existence of some law or authority by which they should be limited. It was not for the court of impeachment at its own capricious pleasure to decide what constituted a high crime or misdemeanor. "There can," he said, "be no crime, there can be no misdemeanor, without a law, written or unwritten, express or implied." Replying to General Butler, one of the impeachment managers, that the Senate could try Johnson for whatever it chose to deem an impeachable offence, Curtis contended that the Constitution of the United States had designated impeachable offences as offences against the United States, had provided for the trial of such offences, establishing a tribunal to try them, and had empowered the tribunal in case of conviction to pronounce judgment and inflict punishment. Such a tribunal was, he argued, a court; it could not be maintained that it was "bound by no law". Speaking of the provision of the Constitution forbidding both the nation and the states to pass any bill of attainder or ex post facto law, he said: 
"According to that prohibition of the Constitution, if every member of this body, sitting in its legislative capacity, and every member of the other body, sitting in its legislative capacity, should unite in passing a law to punish an act after the act was done, that law would be a mere nullity. Yet what is claimed by the honorable managers on behalf of this body? As a Congress, you cannot create a law to punish those acts, if no law existed at the time they were done; but sitting here as judges not only after the fact, but while the case is on trial, you may individually, each one of you, create a law by himself to govern the case.

"According to this assumption, the same Constitution which has made it a bill of rights of the American citizen, not only as against Congress, but as against the legislature of every State in the Union, that no ex post facto law shall be passed,- - this same Constitution has erected you into a body and empowered every one of you to say, Aut inveniam aut faciam,- - if I cannot find a law I will make one'. Nay, it has clothed every one of you with imperial powers: it has enabled you to say, Sic volo, sic jubeo, stat pro ratione voluntas, - ' I am a law unto myself by which I shall govern this case'. And, more than that, when each one of you before he took his place here called God to witness that he would administer impartial justice in this case according to the Court and the laws, he meant such laws as he might make as he went along. $* * *$ I respectfully submit, this view cannot consistently and properly be taken of the character of this body, or of the duties and powers incumbent upon it."

The doctrine that the Court for the Trial of Impeachments created by the Constitution of New York State is not a tribunal with a shadowy, indeterminate, unlimited jurisdiction finds support in the reasonings of Burke and the arguments of Benjamin R. Curtis. The Court has not been clothed with imperial powers; it is not a law unto itself. Its jurisdiction is not so extensive as to authorize it to dismiss the people's servants because in its judgment they are unfit to hold office. This would trench too closely upon the people's power of election by making the power of removal practically co-extensive with it.

These limitations may not have been expressly stated, but they inhere in the frame-work of government and are to be discovered in the fundamental principles of law. Misconduct antedating office seems never to have been a cause of impeachment. There is a contradiction in the terms; the words are meaningless; the wrong-doing which it is the purpose of impeachment to arrest and punish is an act in office or to be consummated in office, as in Guden's case. All prior personal acts, except crimes 
against positive law, are pronounced innocent or are condoned by election; and from that judgment there is no appeal. Crimes against positive law may be established by indictment and trial. The Penal Code provides that conviction shäll be followed by loss of office. When the Constitution prescribes methods of removal, these are not inclusive of, but additional to, those established by the penal law. No person holding the office of governor who had been indicted for and convicted of felony could plead the right to retain office because the organic law had not declared that conviction of felony should be followed by loss of office.

Thus the provisions of the Constitution are harmonized with sound and well recognized principles. Election should bar inquiry into all prior acts that are not crimes against the positive law. As to acts done in the interval between election and assumption of office, there should be no amenability to impeachment because of the impolicy of allowing scrutiny into conduct during this interregnum, lest investigation should result in defeating the people's will. There is no necessity for impeachment for any misconduct done during this time, for if the act be a crime, it is punishable by positive law, and removal from office follows ipso facto upon conviction. It is better to guard jealously the right of the people to the service of the officer they have elected, by forbidding inquiry by the impeaching authorities into his conduct during this interval. If factional or party opposition might impeach him, the temptation at times might become irresistible, especially where, as in New York, impeachment results in removal from office pending a trial before the impeachment court. Election has rendered him immune from responsibility to a court of impeachment not only for acts done before election, but for acts done until he takes office. This was the view of Mr. Justice Gaynor. In Speed v. Common Council of Detroit (98 Mich., 360) and in State v. Common Council of Duluth (53 Minn., 238), it was held that in this country there is no authority to remove a person from office for misconduct occurring before the commencement of his term. As was said in the Michigan case:

"There is no provision in the Constitution nor in the law which prevents a person from holding office for misconduct in another office which he held prior to the one to which he was elected or appointed. We have been unable to find any authority which justifies removal for such previous misconduct. The misconduct for which an officer may be removed must be found in his acts 
and conduct in the office from which his removal is sought, and must constitute a legal cause for his removal, and affect the proper administration of his office."

There should be some boundaries to the jurisdiction of a tribunal that may not only remove from office but also close the door to future office, thus cutting off all chance for popular vindication. To declare that it may remove whomsoever it deems unfit for office is to arm it with anomalous and dangerous power. Impeachment proceedings are quasi-criminal in character, and the law requires acquittal in cases of doubt. This maxim of law applies equally in cases of doubtful jurisdiction. And jurisdiction is doubtful unless it can be convincingly established.

Mistakes made by the people at the polls should not be redressed by recall at the pleasure of an impeachment tribunal. If the people are left to suffer the consequences of their errors they will the sooner learn how important is the work of nomination and election. The ballot is a weapon for good or ill, and the sole security for the future of democracy lies in its wise and intelligent use.

New York City.

\section{J. Hampden Dougherty.}

